\title{
Recognizing Intergenerational Assets Within Religious Communities of Colour
}

\author{
Michael J. Farrow, and JeanMarie Farrow
}

\begin{abstract}
Michael James Farrow earned his EdD at Rowan University in Glassboro, New Jersey, United States. He is currently working as a graduate research assistant within Rowan's education department. He has professional experience as a kindergarten teacher within an urban community of colour. His doctoral research focused on Latino religiosity and its influence on education. Further research interests include the role of Latino and African American religious communities within education, religious-community-school partnerships, and the college choice process. Email: mikefarrow1@yahoo.com
\end{abstract}

JeanMarie Farrow received her PhD with a concentration in literacy and learners at Temple University, Philadelphia, United States. She is currently working with Temple's Family, School, and Community Lab. Her doctoral research focused on teachers' supports of early writing components in prekindergarten and kindergarten classrooms serving low-income children. She has a deep appreciation for the role of language in the human experience, as well as in the process of learning to read and write, and she is particularly interested in researching interventions that help nurture and develop children's foundational oral language skills necessary to later literacy. She recently received the 2019 Student Vocabulary Research Award, American Education Research Association Vocabulary SIG. Email: tug20188@temple.edu

Religious organizations within communities of colour have traditionally been ignored by educational institutions, even though they provide community cultural wealth and literacy assets. While churches are often considered as having nothing to do with school, intergenerational experiences fostered by religious networks positively influence academic achievement and should be considered. In an effort to confront the minority deficit myth and promote a responsive pedagogy, this literature-based position paper promotes the acknowledgment of religion's role in the cultural makeup of many children of colour, and the recognition of the intergenerational assets within marginalized religious social networks.

Keywords: language and literacy; intergenerational learning; cultural responsivity 2008; Muller \& Ellison, 2001). Intergenerational social networks are the building blocks of community. Thus, intergenerational experiences for many children of colour cultivate ways of knowing while transmitting values, meanings, and symbols that are situated in shared experiences extending through generations (Gee, 2004). Children are provided a wealth of assets when they engage in meaning making with older generations.

As collaborating academic researchers within early childhood and cultural studies, we underscore that many recent North American publications may be overlooking cultural factors in their research, which can have the effect of

Religious organizations are important community centres and are integral to supporting intergenerational learning experiences within communities of colour. The intergenerational opportunities afforded by religious organizations marshal literacy assets and community cultural wealth for children of colour. As a result, religiosity is related to academic success for these marginalized children (Antrop-Gonzalez, Velez, \& Garrett, 2005; Barrett, 2010; Donahue \& Benson, 1995; Jeynes, 2003). However, despite research indicating the importance of religious networks for children of colour, there is a paucity of research and scarce attention toward religious organizations' contributions to the lives of marginalized children. Communities that identify with religion are underpinned by value and belief systems, framing cultural perspectives. The lack of attention given to religiosity by educational institutions is a problem, because religion, for many children of colour, is an intricate part of their culture (Dallavis, 2011; Skerrett, 2016) and is an intersection whereby older members can transmit and share the cultural values unique to the community (Glanville, Sikkink, \& Hernández, marginalized religious social networks.

$$
\text { learning, cultural responsivity }
$$


positioning children of colour within a deficit frame. We believe this positioning wrongfully sketches children of colour in need of remediation that has dire academic effects. In response, we take an intergenerational perspective to illuminate the many benefits North American children of colour acquire from their religious social networks: namely, forged relational bonds and rich language and literacy practices. We argue that acknowledgement of religiosity as a component of culture for children of colour contributes to the body of literature detailing the cultural wealth of marginalized communities and, subsequently, combats negative perspectives of difference, relegating minority children to substandard status. We advocate that a culturally responsive pedagogy, as a result, should include consideration of the religious cultures of children of colour, recognizing how religious networks function as intergenerational spaces that contribute toward the academic welfare of marginalized children throughout North America.

\section{Confronting the deficit view of religious children of colour}

Considering religion as an intricate part of cultural identity for children of colour within educational studies takes a perspective of acceptance, of which community cultural wealth theory (Yosso, 2005) frames our argument. Community cultural wealth theory emphasizes the cultural capital found within communities of colour that is often unrecognized by dominant White culture. This theory posits that culture provides advantages that people use to achieve desired ends; thus, it is a socialization process whereby communities enculturate members with, not just relevant skills, but also values, norms, and perspectives, or a lens to understand the world. Emphasized by Tara Yosso's (2005) framework is an asset-based approach that focuses on the knowledge, skills, abilities, and contacts found specifically within communities of colour that have heretofore been misunderstood or classified as deficient by dominant White culture. As such, intergenerational learning experiences are valued within this framework and seen as an important cultural resource for children of colour. Valuing the cultural wealth of marginalized communities directly rejects and combats the presumption that minority children are intrinsically disadvantaged by a lack of culture: the "deficit view."

Unfortunately, the deficit perspectives of students of colour can still be found within education (Bartolomé \& Trueba, 2000; Gregory \& Williams, 2000; Pérez \& Taylor, 2016). The deficit-based myth concerning students of colour is so persistent that it has "the longest history of any explanatory model for understanding the achievement of low-status students discussed in the education literature, and is deeply imprinted in our individual and collective psyches" (Trueba \& Bartolomé, 1997, p. 3). This suggests that many privileged members of the academic community, who come from the dominant culture, have ascribed certain characteristics to marginalized groups which have become ossified over time. Further, these negative stereotypes are perpetuated precisely because the cultures of marginalized communities are so often misunderstood, overlooked, and, worse, dismissed altogether. As an example, Ginwright and Cammarota (2007) point out that educational studies are dominated by researchers focusing on perceived "delinquent" behaviour of Latino and African American students. Hill (2003) points out that a myriad of studies try to link the failures of minority students to dysfunctional communities of colour, portraying families of colour as disorganized, pathological, and disintegrated. Most notably, the dismissal of cultural differences has buttressed language deficit views that have implications for children's literacy and academic success. For example, much research in early childhood studies has focused on language gaps between socioeconomic groups (SES). Low SES children, of which a large majority are children of colour, consistently are shown as lagging behind more affluent peers in standardized tests of language skills. Therefore, the preponderance of children of colour entering school at a disadvantage dominates perspectives and consequently erases the advantages and strengths in language children of colour bring to the classroom. Taken together, children of colour enter school systems dominated with White perspectives that, at best, overlook them and, at worst, silence them. The erasure of children's culture within school systems serving students of colour extends to the erasure of religion from educational consideration. 
In contrast to negative stereotypes that dismiss cultural difference, understanding the importance of intergenerational experiences underscores the community assets of marginalized cultures, of which religion is one. Religion is a strong pervasive force in many communities of colour. Reports of religion's importance as a function of race has shown that people of colour place a higher value on religion and report higher church rate attendance relative to their White counterparts (Pew Research Center, 2009, 2014). More specifically, a plethora of research describes the strong spiritual and religious orientation of African American families as a unique strength of this community (Al-Fadhli \& Kersen, 2010; Barrett, 2010; Freeman, 1986). Likewise, religiosity is a powerful asset within Latino communities, with more than $80 \%$ of Latino families considering themselves to be a part of a religious group, and more than half of Latinos perceiving a great deal of guidance from their religion (Espinosa, Elizondo, \& Miranda, 2003; Pew Research Center, 2014). Moreover, recent research has suggested a rise in pronounced religious identities and an increase in religious vigour among younger generations of children of colour (Platt, 2014; Skerrett, 2016). However, religion has largely been dismissed in considerations of students' culture within school systems. The dismissal, we argue, is systematic of dominant deficit views in that religion's importance to communities of colour is not understood, therefore, not seen and thereby erased by dominant White perspectives. In this way, silencing beliefs and values so integral to the lives of many children of colour can be a form of institutional racism (Jeynes, 2010) perpetuated precisely because of the location of religious communities within communities of colour (Irizarry \& Antrop-González, 2007). In an effort to bring to the forefront the underrecognized educational assets provided by religious communities, the following sections detail the role of intergenerational relationships within African American and Latino churches as providing (1) social assets that function as a bulwark for resiliency and (2) language and literacy assets that reveal rich language uses connected to communities' values.

\section{Community cultural wealth acquired through intergenerational church relationships}

Intergenerational relationships have been shown to provide important social resources to children of colour, and they are an important mechanism in acquiring cultural capital (Barrett, 2000; Irizarry \& Antrop-González, 2007, Liou, Antrop-González, \& Cooper, 2009; Rendón, Nora, \& Kanagala, 2014). Additionally, research specifically underscores religious networks as fostering meaningful intergenerational experiences (Antrop-Gonzalez et al., 2005; Barrett, 2000; Coleman, 1988; Glanville et al., 2008; Muller \& Ellison, 2001). Church networks are one of the few opportunities children of colour have to interact with adult members outside of their family; thus, the transmittal of culture extends to the social group (Glanville et al., 2008). Churches act as a socialization agent that actively seek to form intergenerational bonds where community elders are dedicated to the social development of children (Glanville et al., 2008). As a result, intergenerational contact becomes a meaningful source of socioemotional strength for children that allows them to gain access to advice, resources, and other services that provide information, motivation, and support, which is related to positive educational outcomes (AntropGonzalez et al., 2005).

One positive manifestation of social development attributed to church networks is the mentor-mentee relationship. Research has shown that church networks strive to foster the growth of youth, thus providing a safe haven for children to go to when in need. Within this spirit of nurturing and support, mutual trust between young and old community members foments strong liaisons. These mentoring relationships allow children to interact with ideas and share experiences that promote individual and collective achievement (Ginwright \& Cammarota, 2007) while bolstering self-esteem "through positive reflected appraisals" that influence how children perceive outside opinions about themselves (Muller \& Ellison, 2001, p. 159). When children perceive themselves as accepted and seen in a positive light by their mentors and social circles, like church communities, positive social development occurs as a result (Muller \& Ellison, 2001). 
Socio-religious support is a crucial dimension of academic success for minority children, specifically in urban areas. Tribulations associated with urban settings are mainly the result of oppressive forces of poverty. Children of colour in urban communities, as a result, face an onslaught of personal challenges, whereby community churches become increasingly significant in their role of providing meaningful support for children (Jeynes, 2003; Regnerus \& Elder, 2003). As a result, religiosity is especially influential for children of colour, providing many poor, marginalized children with caring adult support to nurture children and provide scaffolds toward healthy development necessary to academic achievement. Religious communities provide assets for minority children that are not always accumulated through formal education but "are developed strengths through lived experiences, cultural traditions and life challenges which help them" to excel in education (Rendón et al., 2014, p. 4). Support for this comes from qualitative studies showing children of colour continually describe intergenerational experiences as meaningful and connect their relationships within their religious communities to their academic success (Antrop-Gonzalez et al., 2005; Irizarry \& Antrop-González, 2007, Liou et al., 2009; Rendón et al., 2008). Further, studies have found that participation within church networks transpires into higher GPA scores, lower dropout rates, and avoidance of negative behaviours like substance abuse, truancy, gang activity, and suicide (Barrett, 2010; Glanville et al., 2008; Jeynes, 2010; Muller \& Ellison, 2001). Most notably, William Jeynes (2010), in his seminal meta-analysis, examined marginalized student religiosity and its relationship to reducing the achievement gap. The results showed that religious involvement had the highest effect on reducing the minority achievement gap compared to other variables such as family factors, classroom structure, and improved curriculum.

Taken together, highlighting the intergenerational relationships formed within religious churches of colour reveals religiosity as a unique construct in the lives of many marginalized children, providing children a pathway of resiliency to fight oppression. Marginalized community churches provide opportunities for relationship building between younger and older community members that promote interactions that have socioemotional benefits for many marginalized children. The intergenerational social dynamics within religious communities provide essential resources that are used by children of colour for academic achievement. However, we further argue that intergenerational interactions specifically relating to transmittal of culture, as in religious interactions, also entail the transmittal of language uses and practices that underpin marginalized students' literacy assets.

\section{Intergenerational learning providing literacy assets}

The cultural wealth coming from communities of colour also extends to their rich language experiences whereby younger children are enculturated into language uses and purposes of the community. Children's home language is a vital bridge to school language. Specifically, language underpins literacy; thus, language is a crucial contributor of learning how to read and write (Dickinson, Golinkoff, \& Hirsh-Pasek, 2010; Muter, Hulme, Snowling, \& Stevenson, 2004). The problem is a juxtaposition between marginalized children's home language and the language of school, which has contributed to deficit notions of language and, by extension, literacy achievement attributed to minority students.

Traditionally, language and literacy development for young children has been viewed in terms of "skills," creating a "skills focus" pedagogy. Under this frame, children of colour and those coming from low socioeconomic (SES) backgrounds consistently are shown to lag behind their White and more affluent peers in skill acquisition, perpetuating notions of deficiency that help to marginalize these groups of children. However, understanding language and literacy in terms of "events" and their "practices" (Gee, 2001; Street, 2003) can lead to a better understanding of language as being socially constructed. 


\section{Language and culture}

Language is communication and communicative events build children's "ways of knowing" (Heath, 1983). Literacy practices, resulting from events that include reading and writing, reflect cultural perspectives and values embedded within language. Children learn language through exchanges with more expert language users (Vygotsky, 1978). James Paul Gee (2000) explains that language is acculturated and nourished through a type of apprenticeship whereby young children try out language within contexts to learn uses and purposes through feedback and exchanges with more expert language users. According to Gee (2000), the language of a child's home is considered their primary discourse, underscoring that language uses are situated. Language practices of communities reveal the valued ways in which members communicate and, therefore, are inextricably tied to identity and a child's sense of self. We contend that community events for children of colour are intergenerational social spaces that transmit cultural language practices. Additionally, because of the pervasive force of religion in communities of colour, which is committed to socialization of children (Antrop-Gonzalez et al., 2005; Donahue \& Benson, 1995; Jeynes, 2003; Sikkink \& Hernández, 2003; Skerrett, 2016), community churches, in particular, are intergenerational learning spaces whereby older members of the community help to nurture language and literacy practices containing a community's historicity.

\section{Language and ways of knowing}

A small but important body of research exploring language practices of diverse communities has detailed distinct language uses that directly reflect communities' values, beliefs, and expectations (Gee, 2004; Heath, 1983; Labov, 1972; Michaels, 1981; Smitherman, 1977). Importantly, the language uses also have been traced to religious traditions and practices interwoven into a community's cultural fabric. For example, in her seminal study, Shirley Brice Heath (1983) found that African American children coming from Trackton, an impoverished town in North Carolina, tended to tell stories that did not fit expected structures and norms of having a beginning, middle, and end, clearly relaying a theme or message. In contrast, Heath found that children of colour in this neighbourhood tended to tell stories that were open in the sense of inviting various interpretations, feedback, or collaboration to complete the story. Heath surmised that many children in Trackton had to "come to know" in order to participate in community conversations. As such, "to know" often meant to figure out the world by seeing through comparison, acknowledging the complexity of life experiences and life's divergent truths. The most common type of question issued to a child in Trackton, Heath noted, was an analogy, which elicits metaphoric responses. Children, through this type of questioning, were used to telling or showing in ways that invited multiple interpretations. The learned use of language and literacy was traced specifically to Trackton's church, in which older members delivered open sermons and younger members' impromptu responses reflected their "knowing," honouring the verbal adroitness within orality (Delpit, 1995). Hymns that included repetitions, rhymes, and figurative language were distinct language features. Gee (2004) also noted ways of language use having distinct linguistic features for the African American community. He traced the usage of high-level poetic devices, commonly found in the psalms, in African American children's storytelling practices, such as the use of stanza organization with repetitions and parallelism. Other researchers have similarly found differences in language practices attributed to cultural values of a community (Cazden, 1988; Labov, 1972; Michaels, 1981; Smitherman, 1977). These studies illuminate that language practices relate to how marginalized communities use, interpret, and understand the world around them. Put more precisely, using the words of a participant in Heath's (1983) study in relation to how children come to use language, the children "just got to know." And so knowing and language are intimately connected. Moreover, the studies reveal that children of colour possess unique, rich, and varied language practices, beautifully sophisticated in relaying underlying values of the cultural community. Other research has supported rich language uses by both Latino and African American children, especially within contexts more reflective of their home language, such as 
in oral narratives (Craig \& Washington, 2002; Lee, Kang, Jeong, Lopez, \& Fernandez, 2010; Morales \& Lee, 2015). Taken together, the home language children hear from their infancy swaddles the child's knowing, sense of self, and sense of relation to others. It is a language of love and nurturing that surrounds the child's identity. Thus, the home language discourse is the language of acceptance.

\section{Language and difference}

However, the language uses of marginalized communities diverge from more mainstream language uses of the dominant culture. Consequently, these cultural values laced in language have direct implications to the struggles of marginalized children within an educational system that misunderstands and devalues the language practices of marginalized children's homes (Cazden, 1988; Delpit, 1995; Heath, 1983; Michaels, 1981). As such, instead of seeing the strengths and richness of these children's language practices, schools tend to see the home language of minority children as deficient and in need of remediation. A child's language of acceptance in the home is morphed into a language of rejection within the schools. Poor children and children of colour possess rich language and literacy traditions, yet their distinct language practices and ways of knowing do not match up with school language discourse. The result is a tottering bridge between home language and school literacy because marginalized children's language does not pay off in the school system, which regards differences from dominant White language practices as substandard (Gee, 2004).

\section{Language to early literacy: Disconnect in the classroom}

Unfortunately, misunderstanding language differences of the home transpires into a variety of negative effects in the classroom. Sarah Michaels' (1981) qualitative research detailed that many White teachers misunderstood their African American students' language. Analysis of children's storytelling revealed differences in narrative discourse styles between African American and White students. White children typically told stories reflective of school language expectations of stories (e.g., having a beginning, middle, and end, centering the point of a story); however, African American children typically told more episodic narratives (e.g., shifting through interrelated and descriptive scenes). Specifically, she found that White teachers often interrupted, corrected, and judged their African American students' stories as deficient. Her findings aligned with other research showing dismissal and rejection of African American children's language practices (Gee, 2004; Heath, 1983). Additionally, Courtney Cazden (1988) reported differences in teacher judgments based on race. When Black and White teachers were asked to assess the quality of oral narrative skill in transcripts of children's sharing time presentations, White teachers were more likely to judge Black children's stories as "terrible" and "incoherent." However, Black teachers in this study did not perceive Black children's narrative accounts in the same way. In fact, Black teachers believed that the same stories rated as terrible by White teachers were exceptional, with "lots of details and description." The consequence of misperceiving the language of minority children is denigrating their language of home. As such, language development for marginalized children has been stifled precisely because of teacher misjudgment of language capacity and a disregard for the home language of minority children (Fogel \& Ehri, 2008). A further problem with not acknowledging home language practices is the corrosion of children's self-worth and selfefficacy in the classroom because minority children are constantly being shown that their language is inferior, misunderstood, and a reflection of their worth as a student (Delpit, 1995; Gee, 2004). Children whose community language gets reflected as deficient and wrong deal with a myriad of consequences in the classroom that disrupt overall development.

Young children's early cognitive, language, social, and emotional growth are foundational systems that help set the stage for children to be ready to read and write, and these systems are interconnected (Dickinson et al., 2010). Considering that marginalized children are often implicitly silenced in the classroom, it seems plausible that 
minority children may not be experiencing healthy interactions using language that can foster cognitive, emotional, and social growth. The negative consequences to misperceiving language ability include limiting language experiences and limiting engagement in cognitively challenging interactions with supportive adults (Johanson, Justice, \& Logan, 2016). Some research in support of this supposition is work done by Cabell et al. (2011) which found that the amount of responsive strategies by the teacher, defined as quality interactions that support language development (e.g., feedback loops) along with emotional and social supports (e.g., maintaining eye contact and being warm and encouraging) related to language growth only for children who tested higher in language skill ability. The authors concluded that child language ability may be a moderator of teacher input. Put another way, if teachers perceive that children are language deficient, the engagement with the child may be moderated. Teachers may be less inclined to engage in conceptually rich feedback loops if they feel as if their students are inadequate to perform this task. This avoidance on the part of the teacher has ramifications for all early systems of development of the child that are tied to communicative acts, which shape emotional and social growth along with language development. A further example of teachers' perceptions of ability level affecting teacher behaviours comes from work done by Farrow, Wasik, and Hindman (in press). Exploring teachers' complexity of speech to at-risk children in high-poverty schools, the authors found that minority teachers tended to speak using more complex sentences to children in poverty than did White teachers. The authors surmised that because the majority of the children in their sample were African Americans, White teachers may have felt they needed to speak using simpler sentences, misjudging child language ability due to cultural differences, whereas minority teachers, mostly African Americans, did not see the need to speak more simply. Of importance, the researchers also found that the level of complexity of teacher speech uniquely contributed to child vocabulary outcomes. What these studies show is that misjudging child language ability can have negative impacts on minority children's overall development directly related to achievement in school.

\section{Intergenerational literacy assets of marginalized communities}

Although, there is a dearth of research devoted to exploring how marginalized communities' intergenerational language practices support critical developmental systems in young children, some research suggests that marginalized communities do support the emotional and social growth of children through literacy practices, specifically the often overlooked literacy practices grounded in a religious or spiritual orientation. As an example, Cassandra Chaney's (2014) research identified the cultural institution of the African American church and the spiritual and religious orientation of African Americans to be an underlying positive influence in nurturing the emotional and social growth of African American children. Additionally, research has identified intergenerational events provided by the church specific to literacy development, namely, exchanging religious ideas regarding books read, bible reading, reciting prayers, and collaborative writing of sermons and other speeches to the community (Chaney, 2014; Heath, 1983). The literacy events of the church permeate to the homes of minority families; thus, the church nurtures literacy interconnected to emotional and social growth (Chaney, 2014). In regards to early childhood specifically, qualitative studies have substantiated that religious practices support preschoolers' literacy experiences (Johnson, 2010; Kelly, Jarrett, \& Williams-Wheeler, 2016; Teale, 1986). For example, Kelly et al. (2016) found that nighttime prayer was a substantial literacy event in African American homes across SES levels, indicating its permanence as a cultural value to, and a strength of, the African American community; unfortunately, many minority children's home values and cultures are misunderstood and depreciated in school systems that reflect dominant cultural beliefs.

We argue that an intergenerational perspective that includes valuing the religiosity of marginalized communities helps to combat negative language perceptions. Instead of seeing marginalized children as deficient because they do not have "skills" related to dominant language practices, what manifests from an intergenerational perspective 
is the understanding that marginalized children may not have opportunities to display their skills with language because their uses of a language may be unaccepted or unrealized by an education system that is anticipating, expecting, and accepting dominant language uses. Marginalized children's literacy practices are not wrong or deficient, but rather are underpinned with a sophisticated system of communication that reflects cultural values. A strength-based view of marginalized children's home lives is an essential starting point toward transformation within the school systems. Therefore, it is to the advantage of schools and teachers who desire to promote homeschool partnerships to recognize literacy experiences with the older generation as a part of their students learning experiences, including meaningful religious experiences that take place within community organizations.

\section{A pedagogy that responds to religious culture}

Religious networks are multigenerational communities that offer children of colour a host of benefits. Religiosity is a particularly influential factor in the cultural makeup of children of colour, and instead of viewing religious culture as an abnormality to be corrected, culturally responsive education professionals desire to profoundly understand children's religious culture and recognize the community cultural wealth that religious networks provide. Unfortunately, churches, as organizations within communities of colour, have been subjected to the same deficit myths and misunderstandings (Irizarry \& Antrop-González, 2007; Jeynes 2010). The religious identity of children of colour is dismissed, and their cultural wealth, as a result, is ignored. Therefore, marginalized children's culture is erased from school settings.

Erasing the cultural lives of marginalized children is essentially setting up disconnects between children's home and school lives, resulting in marginalized children feeling as if school is not a part of who they are, not part of their identity (Gee, 2004; Delpit, 1995). The resultant effect can dovetail into two problematic results. The first is disengagement with school because marginalized children do not want to deny the nurturing of their home lives as part of understanding the world (Boutte, 2012). Second, the continuity of failure reflected onto marginalized children because their way of doing, way of knowing, and way of speaking deviate in comparison to White children, positions marginalized children as substandard within the classroom. These relegated positions in classrooms have negative psychological effects. Positive identity development is widely recognized as having profound implications for children of colour (Alfaro et al., 2009; Moses, 2000; Steel, Spencer, \& Aronson, 2009; Sung, 2015; Torres, Jones, \& Renn, 2009; Umana-Taylor, Gonzales-Backen, \& Guimond, 2009), because for marginalized children, identity is compared to and evaluated against the norms of White privileged culture (Phinney, Romero, Nava, \& Huang, 2001). Within school systems, many marginalized children have reflected onto them a contorted vision painted by deficit myth perspectives, impacting their self-esteem, self-worth, self-efficacy, and, consequently, motivation. Rejection of cultural differences is erasure of marginalized children's identity. It is this rejection that perpetuates academic failure. Marginalized children's failure is the failure of school systems to recognize the beauty and wealth crafting distinct cultures. In response, we advocate for a culturally responsive pedagogy as one of acceptance, valuing the life experiences of many marginalized children. Valuing, in turn, seeks to bridge children's community lives to school, so that school identity is not immiscible with cultural identity. The importance of identity to education includes consideration of intersections with religious identities (Dallavis, 2011; Hallett \& Venegas, 2015; Skerrett, 2016).

Unfortunately, this tendency of deficit perspectives to devalue religious identity hinders effective pedagogy that engages diverse students (Dallavis, 2001; Skerrett, 2016). Out of fear of mishandling sensitive conversations, White teachers tend to ignore race and ethnicity (Lensmire, 2012), as well as different religious cultures (Skerrett, 2016). Teacher avoidance is a microcosm of the dismissive disposition the school system typically takes in regards to issues of marginalized cultures, including religious cultures. Public school systems have historically avoided 
acknowledgement of religiosity due to fears of religious controversy and violating policies that prevent the endorsement of a particular religion (Skerrett, 2016). This sadly results in the neglect of a crucial component of culture for students of colour, and, when student cultures are dismissed by school systems, a negative impact on education can be expected (Gay, 1999). A pedagogy that seeks to bridge the community lives of children to school is necessary, but is a stark transition from the traditional avoidance that is so prevalent.

A better understanding of student culture can help to provide a more effective culturally responsive pedagogy (Gay, 1999; Sleeter, 2012), and for many students of colour, this includes religious identities cultivated by local community churches (Dallavis, 2011; Skerrett, 2016; Veneers \& Hallett, 2013). The disconnect between school systems and children of colour who identify with religion can be addressed by seeing religion as a cultural resource that requires recognition and an appropriate pedagogical response (Dallavis, 2001). Even though the secular setting of public schools makes addressing religious identity and faith complex, public school professionals should nevertheless be encouraged to consider how the intergenerationality of religious social networks can be used to close achievement gaps.

One promising avenue is using community churches to help bolster literacy practices (Chaney, 2014). For example, many home literacy outreach programs target adult book reading with children (Chance, 2010; Stoltz, Czarnecki, \& Wilson, 2013; Wasik, 2004). Some of this outreach includes making sure children have access to books or writing materials, but also encourages family members to read with children on a daily basis. However, extending these initiatives to include community churches provides further nurturing literacy opportunities and should be a part of home-school outreach programs (Chaney, 2014). For example, book reading within community churches may include texts chosen by Church members to read with younger members. Additionally, outreach programs that include writing with older Church members may be another promising avenue.

Within the classroom, a strength-based approach can be used as a bridge to school learning. In one respect, acceptance of a child's culture can have motivating effects, but it can also be used to harness high expectations (Delpit, 1995; Lee, 2000). The view that school language is a type of discourse, a language system that can be learned, invites marginalized children to use that language to achieve certain academic purposes. From this perspective, ownership and authority are transferred back to the children (Delpit, 1995). Marginalized children bring a wealth of language features to the classroom that teachers can use to bridge into high academic language instruction. In other words, children of colour do not need to be talked down to or given less conceptually demanding activities. They just need to be shown the covert rule book of school language (Delpit, 1988), while at the same time marshalling the wealth of their home language. For instance, allowing children of colour to "shift" in their narrative retellings followed by explicit connection making in which children use language to explain how two things are interconnected both values their home language while at the same time supports uses of school language in classrooms.

In light of the research that demonstrates the profound intergenerational support provided by religious organizations within communities of colour, it is incumbent upon teachers, education leaders, policy makers, and researchers to find means to culturally respond to the religiosity of students of colour.

\section{Conclusion}

Religious organizations within communities of colour have traditionally been ignored by education scholars and practitioners alike, even though, through intergenerationality, they provide literacy assets and community cultural wealth (Irizarry \& Antrop-González, 2007; Liou et al., 2009). Gregory and Williams (2000) contend that it is the "awareness of this wealth that best exposes as groundless the deficit myth" (p. 1). Expanding their assertion, we find that recognition of intergenerational experiences in community churches for children 
of colour can assist in forging community-school understandings that promote success for these traditionally marginalized students. While churches are often looked at as having nothing to do with school, research suggests that intergenerational experiences fostered by religious networks directly influence academic achievement and should be considered by academics and practitioners (Antrop-Gonzalez et al., 2005; Glanville et al., 2008). Taking into consideration that religious social networks offer meaningful intergenerational relationships for children of colour, educational institutions can promote attention to community cultural wealth and literacy assets generating from intergenerational contact within neighbourhood religious networks. Means of culturally responding to the religious cultures can be supported by recognizing the contributions of religious networks toward the academic welfare of children of colour, through the rich intergenerational experiences they offer. 


\section{References}

Al-Fadhli, H. M., \& Kersen, T. M. (2010). How religious, social, and cultural capital factors influence educational aspirations of AfricanAmerican adolescents. The Journal of Negro Education, 79, 380-389.

Alfaro, E. C., Umaña-Taylor, A. J., Gonzales-Backen, M. A., Bámaca, M. Y., \& Zeiders, K. H. (2009). Latino adolescents' academic success: The role of discrimination, academic motivation, and gender. Journal of Adolescence, 32(4), 941-962. https://doi.org/10.1016/j. adolescence.2008.08.007

Antrop-Gonzalez, R., Velez, W., \& Garrett, T. (2005). Donde estan los estudiantes Puertorriquenos/os exitosos? [Where are the academically successful Puerto Rican students?]: Success factors of high-achieving Puerto Rican high school students. Journal of Latinos and Education, 4(2), 77-94. https://doi.org/10.1207/s1532771xjle0402_2

Barrett,B.D.(2010).Religionandhabitus:Exploringtherelationshipbetweenreligiousinvolvementandeducationaloutcomesandorientations among urban African-American students. Urban Education, 45, 448-479. https://doi.org/10.1177\%2F0042085910372349

Bartolomé, L. I., \& Trueba, E. T. (2000). Immigrant voices: In search of educational equity. Lanham, MD: Rowman \& Littlefield.

Boutte, G. S. (2012). Urban schools: Challenges and possibilities for early childhood and elementary education. Urban Education, 47(2), 515-550. https://doi.org/10.1177\%2F0042085911429583

Cabell, S. Q., Justice, L. M., Piasta, S. B., Curenton, S. M., Wiggins, A., Turnbull, K. P., \& Petscher, Y. (2011). The impact of teacher responsivity education on preschoolers' language and literacy skills. American Journal of Speech-Language Pathology, 20(4), 315-330. https://doi.org/10.1044/1058-0360(2011/10-0104)

Cazden, C. B. (1988). Classroom discourse: The language of teaching and learning. Portsmouth, NH: Heinemann.

Chance, R. (2010). Family literacy programs: Opportunities and possibilities. Teacher Librarian, 37, 8-12.

Chaney, C. (2014). Bridging the gap: Promoting intergenerational family literacy among low-income, African-American families. Journal of Negro Education, 83(1), 29-48. http://dx.doi.org/10.7709/jnegroeducation.83.1.0029

Coleman, J. (1988). Social capital in the creation of human capital. American Journal of Sociology, 94, S95-S120. https://doi. org/10.1086/228943

Craig, H. K., \& Washington, J. A. (2002). Oral language expectations for African-American preschoolers and kindergarteners. American Journal of Speech-Language Pathology, 11, 59-70. https://doi.org/10.1044/1058-0360(2005/013)

Dallavis, C. (2011). "Because that's who I am": Extending theories of culturally responsive pedagogy to consider religious identity, belief, and practice. Multicultural Perspectives, 13(3), 138-144. https://doi.org/10.1080/15210960.2011.594375

Delpit, L. D. (1988). The silenced dialogue: Power and pedagogy in educating other people's children. Harvard Educational Review, 58(3), 280-298. Retrieved from http://Imcreadinglist.pbworks.com/f/Delpit+(1988).pdf

Delpit, L. D. (1995). Other people's children: Cultural conflict in the classroom. New York, NY: New Press.

Dickinson, D. K., Golinkoff, R. M., \& Hirsh-Pasek, K. (2010). Speaking out for language: Why language is central to reading development. Educational Researcher, 39(4), 305-310. https://doi.org/10.3102\%2F0013189X10370204

Donahue, M. J., \& Benson, P, L. 1995. Religion and the well-being of adolescents. Journal of Social Issues, 51,145-60.

Espinosa, G., Elizondo, V. P., \& Miranda, J. (2003). Hispanic churches in American public life: Summary of findings. Notre Dame, IN: Institute for Latino Studies, University of Notre Dame.

Farrow, J., Wasik B., \& Hindman, A. (in press). Exploring the unique contribution of teachers' syntax to preschoolers' and kindergarteners' vocabulary learning. Early Childhood Research Quarterly.

Fogel, H., \& Ehri, L. C. (2006). Teaching African-American English forms to standard American English-Speaking teachers: Effects on acquisition, attitudes, and responses to student use. Journal of Teacher Education, 57(5), 464-480. (ERIC Document Reproduction 
Service No. EJ745780).

Freeman, R. B. (1986). Who escapes? The relation of churchgoing and other background factors to the socioeconomic performance of Black males from intercity poverty tracts. In R. B. Freeman \& H. J. Holzer (Eds.), The Black youth employment crisis (pp. 353-376). Chicago, IL: University of Chicago Press.

Gay, G. (1999). Educational quality for students of color. In J. A. Banks \& C. A. M. Banks (Eds.), Multicultural education: Issues and perspectives (3rd ed., pp. 195-228). Toronto, ON: Allyn \& Bacon.

Gee, J. (2000). Identity as an analytic lens for research in education. Review of Research in Education, 25, 99-125. https://doi. org/10.3102\%2F0091732X025001099

Gee, J. (2001). Reading as situated language: A sociocognitive perspective. Journal of Adolescent \& Adult Literacy, 44(8), 714-725. https:// doi.org/10.1598/JAAL.44.8.3

Gee, J. P. (2004). Situated language and learning: A critique of traditional schooling. London, UK: Routledge.

Ginwright,S., \&Cammarota,J.(2007). Youthactivismin theurbancommunity:Learningcriticalcivicpraxiswithincommunityorganizations. International Journal of Qualitative Studies in Education, 20(6), 693-710. https://doi.org/10.1080/09518390701630833

Glanville, J. L., Sikkink, D., \& Hernández, E. I. (2008). Religious involvement and educational outcomes: The role of social capital and extracurricular participation. The Sociological Quarterly, 49(1), 105-137. https://doi.org/10.1111/j.1533-8525.2007.00108.x

Gregory, E., \& Williams, A. (2000). City literacies: Learning to read across generations and cultures. London: Routledge.

Hallett, R. E., \& Venegas, K. (2015). Socially influenced decision-making and Latino college student experiences in the United States: Introduction to the issue. The Journal of Latino / Latin American Studies, 7(2), 99-101. https://doi.org/10.18085/1549-95027.2.99

Heath, S. B. (1983). Ways with words: Language, life, and work in communities and classrooms. New York, NY: Cambridge University Press.

Hill, R. B. (2003). The strengths of Black families (2nd ed.). Lanham, MD: University Press of America.

Irizarry, J., G. \& Antrop-González, R. (2007). RicanStructing the discourse and promoting school success: Extending a theory of culturally responsive pedagogy for diasporicans. Centro Journal, 19(2), 37-59. Retrieved from https://www.redalyc.org/articulo. oa?id=37719203

Jeynes, W. H. (2003). The effects of religious commitment on the academic achievement of urban and other children. Education and Urban Society 36, 44-62. https://doi.org/10.1177\%2F0013124503257206

Jeynes, W. H. (2010). Religiosity, religious schools, and their relationship with the achievement gap: A research synthesis and metaanalysis. The Journal of Negro Education, 79, 263-279. https://www.jstor.org/stable/20798348

Johanson, M., Justice, L. M., \& Logan, J. (2016). Kindergarten impacts of a preschool language-focused intervention. Applied Developmental Science, 20(2), 94-107. http://dx.doi.org/10.1080/10888691.2015.1074050

Johnson, A. S. (2010). The Jones family's culture of literacy. The Reading Teacher, 64, 33-44. https://doi.org/10.1598/RT.64.1.4

Kelly, J., Jarrett, R., \& Williams-Wheeler, M. (2016). “We pray, and we read ... I let them watch some TV”: African American preschoolers' bedtime experiences with literacy. The Western Journal of Black Studies, 40(3), 174-191.

Labov, W. (1972). Language in the inner city. Philadelphia: University of Pennsylvania.

Lee, C. D. (2004). Signifying in the zone of proximal development. In C. D. Lee \& P. Smagorinsky (Eds.), Vygotskian perspectives on literacy research: Constructing meaning through collaborative inquiry (pp. 191-225). Cambridge, UK: Cambridge University Press.

Lee, J. S., Kang, P., Jeong, E., Lopez, V., \& Fernandez, G. (2010). Understanding the influence of settings on dual language competence among Korean and Mexican immigrant children. Paper presented at the meeting of the American Educational Research Association, Denver, Colorado, May 4. 
Lensmire, A. (2012). White urban teachers: Stories of fear, violence, and desire. Lanham, MD: Rowman \& Littlefield Education.

Liou, D. D., Antrop-González, R., \& Cooper, R. (2009). Unveiling the promise of community cultural wealth to sustaining Latina/o students' college-going information networks. Educational Studies, 45(6), 534-555. https://doi.org/10.1080/00131940903311347

Michaels, S. (1981). "Sharing time": Children's narrative styles and differential access to literacy. Language in Society, 10(3), 423-442. https://doi.org/10.1017/S0047404500008861

Morales, M., \& Lee, J. S. (2015). Stories of assessment: Spanish-English bilingual children's agency and interactional competence in oral language assessments. Linguistics and Education, (29), 32-45. http://dx.doi.org/10.1016\%2Fj.linged.2014.10.008

Moses, M. S. (2000). Why bilingual education policy is needed: A philosophical response to the critics. Bilingual Research Journal, 24(4), 333-354. https://doi.org/10.1080/15235882.2000.10162771

Muller, C., \& Ellison, C. G. (2001). Religious involvement, social capital, and adolescents' academic progress: Evidence from the National Educational Longitudinal Study of 1988. Sociological Focus, 34, 155-183. https://doi.org/10.1080/00380237.2001.10571189

Muter, V., Hulme, C., Snowling, M. J., \& Stevenson, J. (2004). Phonemes, rimes, vocabulary, and grammatical skills as foundations of early reading development: Evidence from a longitudinal study. Developmental Psychology, 40, 665-681. https://doi.org/10.1037/00121649.40.5.665

Pérez, D., II, \& Taylor, K. B. (2016). Cultivando logradores: Nurturing and sustaining Latino male success in higher education. Journal of Diversity in Higher Education, 9, 1-19. (ERIC Document Reproduction Service No. EJ1091995).

Pew Research Center. (2009). A religious portrait of African-Americans. Retrieved from https://www.pewforum.org/2009/01/30/areligious-portrait-of-african-americans/

Pew Research Center. (2014). The shifting religious identity of Latinos in the United States: Nearly one in four are former Catholics. Retrieved from https://www.pewforum.org/2014/05/07/the-shifting-religious-identity-of-latinos-in-the-united-states/

Phinney, J. S., Romero, I., Nava, M., \& Huang, D. (2001). The role of language, parents, and peers in ethnic identity among adolescents in immigrant families. Journal of Youth and Adolescence, 30, 135-157. http://dx.doi.org/10.1023/A:1010389607319

Platt, L. (2014). Is there assimilation in minority groups' national, ethnic, and religious identity? Ethnic and Racial Studies, 37(1), 46-70. https://doi.org/10.1080/01419870.2013.808756

Regnerus, M. D., \& Elder G. H. (2003). Religion and vulnerability among low-risk adolescents. Social Science Research 32, 633-658. https://doi.org/10.1016/S0049-089X(03)00027-9

Rendón, L. I., Nora, A., \& Kanagala, V. (2014). Ventajas/assets y conocimientos/knowledge: Leveraging Latin@ strengths to foster student success. San Antonio, TX: The University of Texas at San Antonio, College of Education \& Human Development, Center for Research and Policy in Education. Retrieved from https://www.utsa.edu/strategicplan/documents/2017_12\%20Student\%20 Success\%20_Ventajas_Assets_2014.pdf

Sikkink, D., \& Hernández, E. (2003, January). Religion matters: Predicting schooling success among Latino youth. Interim Report, Vol. 1. Institute for Latino Studies, University of Notre Dame, Notre Dame, Indiana.

Skerrett, A. (2016). “Closer to God”: Following religion across the lifeworlds of an urban youth. Urban Education, 51(8), 964-990. https:// doi.org/10.1177\%2F0042085914549365

Sleeter, C. (2012). Confronting the marginalization of culturally responsive pedagogy. Urban Education, 47(3), 562-584. https://doi. org/10.1177\%2F0042085911431472

Smitherman, G. (1977). Talking and testifying: The language of Black America. Boston, MA: Houghton Mifflin.

Steel, C. M., Spencer, S. J., \& Aronson, J. (2002). Contending with group image: The psychology of stereotype and social identity threat. In M. Zanna (Ed.), Advances in experimental social psychology (Vol. 34; pp. 379-440). San Diego, CA: Academic Press.

Stoltz, D., Czarnecki, E., \& Wilson, C. (2013). Every child ready for school: Helping adults inspire young children to learn. Chicago, IL: 
American Library Association.

Street, B. V. (2003). What's "new" in new literacy studies? Critical approaches to literacy in theory and practice. Current Issues in Comparative Education, 5(2), 77-91. Retrieved from https://www.tc.columbia.edu/cice/pdf/25734_5_2_Street.pdf

Sung, K. (2015). "Hella ghetto!": (Dis)Locating race and class consciousness in youth discourses of ghetto spaces, subjects, and schools. Race Ethnicity and Education, 18(3), 363-395. https://doi.org/10.1080/13613324.2013.792799

Teale, W. H. (1986). Home background and young children's literacy development. In W. H. Teal \& E. Sulzby (Eds.), Emergent literacy: Writing and reading (pp. 156-172). Norwood, NJ: Ablex.

Torres, V., Jones, S. R., \& Renn, K. A. (2009). Identity development theories in student affairs: Origins, current status, and new approaches. Journal of College Student Development, 50(6), 577-596. Retrieved from https://msu.edu/ renn/TorresJonesRenn2009.pdf

Trueba, E. T., \& Bartolomé, L. I. (1997). The education of Latino students: Is school reform enough? ERIC/CUE Digest, 123. (ERIC Document Reproduction Service No. ED 410367).

Umana-Taylor, A. J., Gonzales-Backen, M. A., \& Guimond, A. B. (2009). Latino adolescents' ethnic identity: Is there a developmental progression and does growth in ethnic identity https://doi.org/10.1111/j.1467-8624.2009.01267.x predict growth in self-esteem? Child Development, 80(2), 391-405.

Vygotsky, L. S. (1978). Mind in society: The development of higher psychological processes. Cambridge, MA: Harvard University Press.

Wasik, B. (Ed.). (2004). Handbook of family literacy. Mahwah, NJ: Lawrence Erlbaum.

Yosso T. J. (2005). Whose culture has capital? A critical race theory discussion of community cultural wealth. Race Ethnicity and Education, 8(1), 69-91. https://doi.org/10.1080/1361332052000341006 